\title{
DNA dependent - RNA polymerase activity in the chicken liver and breast muscle after protein restriction
}

\section{K. Kochman, Irena Kędzierska and Helena Kochman}

The Kielanowski Institute of Animal Physiology and Nutrition, Polish Academy of Sciences, 05-110 Jablonna near Warsaw, Poland

(Received 6 August 1993; accepted 6 September 1993)

\begin{abstract}
The experiment was carried out on 36 one-day-old chickens fed to appetite a starter feed for broilcrs up to the age of 11 days. At this time 6 chickens (group zero) were sacrified. The remaining birds were divided into 3 groups: control $(C)$, undernourished $(U)$ and realimented $(R)$. Two isocaloric diets with different protein content $(12.9 \% \mathrm{LP}$ and $22.6 \% \mathrm{HP})$ were force fed.

The experiment was divided into two periods: during the first the mean body weight increased from 134 to $250 \mathrm{~g}$ and during the second from 250 to $450 \mathrm{~g}$. Throughout the experiment chickens $\mathrm{C}$ were fed the HP diet, chickens from $\mathrm{U}$ group the $\mathrm{LP}$ diet. The $\mathrm{R}$ group received LP diet and then, in the second period, HP diet. At the end of the first period 6 chickens from the $\mathrm{C}$ group and 6 from the $\mathrm{U}$ group, and at the end of the second period 6 chicken from $\mathrm{C}, \mathrm{U}$ and $\mathrm{R}$ groups were sacrified to determine RNA polymerases activity in liver and breast muscle. Applied feeding regime had no significant effect on polymerase I and II activity in the liver. On the other hand it evoked significant increase of activity of these enzymes in breast muscle of $R$ chickens. This suggests possibility of regulation of protein biosynthesis on the level of transcription by changing either content or activity of RNA polymerases.
\end{abstract}

KEY WORDS: chicken, protein level, RNA polymerases activity

\section{INTRODUCTION}

It is well known that the primary control of gene expression lies at the level of gene transcription, many genes being transcribed only in particular tissues where their protein products are required. Genes which are regulated in parallel in response to a particular inducing signal or in a particular tissue have been shown to contain common DNA sequence elements which are often but not always located up-stream of the start of transcription.

ISSN 1230-1388 C Institute of Animal Physiology and Nutrition 
In spite of many research efforts the molecular basis for the broad range of growth regulation in different tissues and in whole organism is still poorly undestood.

Growth hormone and growth factors are major regulators of postnatal growth and intermediary metabolism. The mechanism by which they exert these regulatory effects at the molecular level is largely unknown. The interaction between $\mathrm{GH}$ and its specific membrane-bound receptor is believed to lead to a number of effects, including changes in metabolism, gene expression, cell proliferation and differentiation.

It has been believed for some time that certain DNA sequence elements could act by binding specific regulatory proteins. These transcription factors would interact with each other and RNA polymerase enzyme itself in order to modulate transcription (Latchman, 1990).

The measurement of RNA polymerase activity can be a good indicator of protein biosynthesis ability in the specific tissue. DNA-dependent RNA polymerases (EC 2.7.7.6) from eukaryotes have been separated into two major groups by ion-exchange chromatography (Roeder and Rutter, 1969). Polymerase I (or enzyme A) is localized in the nucleolus and appears to be responsible for the synthesis of precursor ribosomal RNA (Roeder and Rutter, 1972). Polymerase II (or enzyme B) is localized in the nucleoplasm and is recognized by its sensitivity to the toxin $\alpha$-amanitin (Kedinger et al., 1970; Lindel et al., 1970). Polymerase II appears to be involved in the synthesis of mRNA (Zylber and Penman, 1971). Transcription of tRNA and 5S RNA genes by a third enzyme designated polymerase III has been described (Weinmann and Roeder, 1974).

Von der Decken and Andersson (1972) showed that RNA polymerase activity as measured in whole nuclei of liver was significantly different between rats fed on a diet containing either 20 or $3 \%$ high-quality protein. The apparent alterations in activity could be ascribed either to differences in amount or activity of the enzymes themselves or in availability of DNA template to be transcribed.

Evidence is presented here that the enzyme activities are closely related to the dietary protein intake, and therefore at least partially responsible for the differences in RNA synthesis observed (von der Decken and Andersson, 1972). Andersson and von der Decken (1975) found that a decrease in dietary protein content from 20 to $3 \%$ induces a fall of level and specific activity of RNA polymerases I and II in rat liver.

\section{MATERIALS AND METHODS}

The experiments were carried out on 36 one-day-old male chickens (Cornish $\times$ White Rock). The chickens were kept in wire mesh cages: 5-6 per cage at a temperature of $24-26^{\circ} \mathrm{C}$. Infrared bulbs over the cages supplied additional heat. 
Up to the age of 11 days the birds were fed to appetite on starter feed for broilers. At this age 6 chickens, weighing on the average $143 \mathrm{~g}$, were killed (group zero) whereas the remaining were divided into three groups: control, undernourished (low-protein diet) and realimented.

TABLE 1

Composition of diets

\begin{tabular}{lcc}
\hline & \multicolumn{2}{c}{ Diet } \\
Ingredient, \% & A & B \\
\hline Ground maize & 45 & 45 \\
Ground wheat & 20 & 20 \\
Soya bean oil meal & 4 & 4 \\
Wheat starch & 6.15 & 18.15 \\
Yeast & 2 & 2 \\
Fish meal & 6 & 6 \\
Casein & 12 & - \\
Limestone & 1 & 1 \\
Dicalcium phosphate & 1 & 1 \\
Sodium chloride & 0.1 & 0.1 \\
Soya oil & 1.75 & 1.75 \\
Polfamix DKA* & 1 & 1 \\
\hline Crude protein, \% & 22.56 & 12.87 \\
Metabolizable energy, MJ & 13.42 & 13.20 \\
\hline
\end{tabular}

* Standard mixture containing vitamins, minerals and coccidiostatics

In the experiment two different diets were used (Table 1) of similar metabolizable energy (about $13 \mathrm{MJ}$ ) but considerably different protein levels, namely 12.9 (B) and $22.6 \%$ DM (A). In order to ensure standard feeding level the chickens were force-fed as described by Kielanowski and Keller (1962). The feed was finely ground and mixed with water in proportion 100 to $125 \mathrm{~g}$. The amount of dry matter of the diet given daily amounted to $15 \%$ of the mean body weight of that particular group, established every two days by weighing all chickens. The birds were fed three times daily: at $8.00,14.00$ and $20.00 \mathrm{~h}$ with free access to water.

The experiment was divided into two periods: during the first the average body weight of the chickens increased from 143 to $250 \mathrm{~g}$, during the second from 250 to $450 \mathrm{~g}$ (Tables 2 and 3). The chickens of the control group were fed diet A during both periods, of the undernourished group on the diet $B$, and the realimented group diet $\mathrm{B}$ for the first period and diet A during the second.

At the end of the first period 6 birds from the control group and from low-protein group were killed for analyses. The chickens from the realimented group since that time were fed on the diet A. At the end of the second period 
TABLE 2

RNA polymerase I and II activity in the liver of chicken

\begin{tabular}{|c|c|c|c|c|c|c|}
\hline \multirow[t]{2}{*}{ Groups } & \multirow{2}{*}{$\begin{array}{c}\text { Mean } \\
\text { body } \\
\text { weight } \\
\mathrm{g}\end{array}$} & \multirow{2}{*}{$\begin{array}{c}\text { Protein } \\
\text { content } \\
\text { in the diet } \\
\%\end{array}$} & \multicolumn{2}{|c|}{$\begin{array}{l}\text { RNA polymerase activity } \\
\text { pmole }{ }^{3} \mathrm{H}-\mathrm{UTP} / \mathrm{g} \text { tissue }\end{array}$} & \multicolumn{2}{|c|}{$\begin{array}{c}\text { Percentage participation } \\
\text { of polymerase }\end{array}$} \\
\hline & & & I & II & I & II \\
\hline \multirow[t]{2}{*}{ Control } & 246 & 22.6 & $450 \pm 267$ & $254 \pm 80$ & 64 & 36 \\
\hline & 452 & 22.6 & $787 \pm 308$ & $261 \pm 85$ & 75 & 25 \\
\hline Low- & 242 & 12.9 & $515 \pm 312$ & $260 \pm 130$ & 66 & 33 \\
\hline protein & 441 & 12.9 & $275 \pm 40$ & $206 \pm 186$ & 57 & 43 \\
\hline Realimen- & 242 & 12.9 & $515 \pm 312$ & $260 \pm 130$ & 66 & 33 \\
\hline ted & 461 & 22.6 & $536 \pm 195$ & $234 \pm 30$ & 70 & 30 \\
\hline
\end{tabular}

TABLE 3

RNA polymerase I and II activity in breast muscle of chicken

\begin{tabular}{|c|c|c|c|c|c|c|}
\hline \multirow[t]{2}{*}{ Groups } & \multirow{2}{*}{$\begin{array}{c}\text { Mean } \\
\text { body } \\
\text { weight } \\
\mathrm{g}\end{array}$} & \multirow{2}{*}{$\begin{array}{c}\text { Protein } \\
\text { content } \\
\text { in the diet } \\
\%\end{array}$} & \multicolumn{2}{|c|}{$\begin{array}{l}\text { RNA polymerase activity } \\
\text { pmole }{ }^{3} \mathrm{H}-\mathrm{UTP} / \mathrm{g} \text { tissue }\end{array}$} & \multicolumn{2}{|c|}{$\begin{array}{c}\text { Percentage participation } \\
\text { of polymerase }\end{array}$} \\
\hline & & & I & II & I & II \\
\hline \multirow[t]{2}{*}{ Control } & 246 & 22.6 & $289 \pm 112$ & $71 \pm 44$ & 80 & 20 \\
\hline & 452 & 22.6 & $197 \pm 34^{a, b}$ & $65 \pm 17$ & 75 & 25 \\
\hline Low- & 242 & 12.9 & $117 \pm 47$ & $45 \pm 30$ & 72 & 28 \\
\hline protein & 441 & 12.9 & $136 \pm 52^{b}$ & $68 \pm 31$ & 67 & 33 \\
\hline Realimen- & 242 & 12.9 & $117 \pm 47^{A}$ & $45 \pm 30^{A}$ & 72 & 28 \\
\hline ted & 461 & 22.6 & $260 \pm 74^{a B}$ & $109 \pm 51^{B}$ & 70 & 30 \\
\hline
\end{tabular}

Values with the different superscript are statistically significant

$\mathrm{a}, \mathrm{b}-\mathrm{P}<0.05$

A, B $-\mathrm{P}<0.01$

6 chickens from each of the three groups were killed. Immediately after killing the samples of liver (approximately $1.5 \mathrm{~g}$ ) and of the breast muscles from the right side (approximately $2 \mathrm{~g}$ ) were taken. Both liver and muscle samples were stored in vials placed into a flask with dry-ice until analysis.

Chemicals were of analytical grade wherever possible. ATP, GTP, CTP UTP and DNA were purchased from Sigma Chemical Co., St. Louis, Mo., U.S.A; $\left[5,6{ }^{3} \mathrm{H}\right]$ uridine 5 -triphosphate $(45 \mathrm{Ci} / \mathrm{mmol})$ from Amersham, U.K.; dithiothreitol (Cleland's reagent) from Calbiochem A.G., Lucerne, Switzerland. 


\section{Determinations of the DNA-dependent RNA polymerases activity}

Preparation and purification of nuclei from liver and muscle cells was performed according to the method described by Chomczyński and Topper (1974). Samples of liver and breast muscle tissue were homogenized in a three times larger volume of the buffer $(0.25 \mathrm{M}$ saccharose, $0.20 \mathrm{mM}$ buffer Tris- $\mathrm{HCl}$ $\mathrm{pH} 7.8,2 \mathrm{mM} \mathrm{MgCl}_{2}$ and $1 \mathrm{mM}$ dithiothreitol). The nuclei were purified by sedimentaion in $1.8 \mathrm{M}$ saccharose solution.

RNA polymerases from liver and breast muscle of chickens were transferred to the solution and purified according to the method of Roeder (1974). Enzymatic preparation containing both I and II polymerases were determined either in presence or absence of $\alpha$-amanitin which selectively inhibits activity of polymerase II. The volume of incubated mixture containing dissolved RNA polymerases amounted to $75 \mu \mathrm{l}$ according to the method of Roeder (1974). The mixture was incubated at $30^{\circ} \mathrm{C}$ for $30 \mathrm{~min}$, as described by Kleczkowska and Chomczyński (1976). Activity of polymerase II was calculated by substracting from total synthetized RNA the amount of RNA whose synthesis by polymerase I insensitive to action of $\alpha$-amanitin.

Activity of polymerase I was calculated by substracting the value of the blank sample with actinomycin $\mathrm{D}(10 \mu \mathrm{g} / \mathrm{ml})$ from the sample with $\alpha$-amanitin.

The amount of protein in the samples was estimated by the method of Lowry et al. (1951) and DNA was estimated using diphenylamine reaction (Burton, 1956).

\section{RESULTS}

Activity of RNA polymerases in the liver

\section{Activity of polymerase I}

No significant differences were found in activity of polymerase $I$ in the liver of control, low-protein and realimented chickens (Table 2). In liver of the undernourished chickens the activity was much lower $(275 \pm 40$ pmole ${ }^{3} \mathrm{H}-\mathrm{UTP} / \mathrm{g}$ tissue) than in the liver of the chickens from the remaining groups $\left(536 \pm 193\right.$ and $787 \pm 308$ pmole ${ }^{3} \mathrm{H}-\mathrm{UTP} / \mathrm{g}$ tissue). However, these differences were statistically not significant, probably due to great variability of activities within each group.

\section{Activity of polymerase II}

In the liver of the chickens no significant differences among groups of polymerase II activity were found (Table 2 ). 
In the case of polymerase I activity of the enzyme was similar in the liver of the chickens from control $\left(261 \pm 85\right.$ pmole ${ }^{3} \mathrm{H}-\mathrm{UTP} / \mathrm{g}$ tissue $)$ and realimented groups ( $234 \pm 30$ pmole ${ }^{3} \mathrm{H}-\mathrm{UTP} / \mathrm{g}$ tissue) and lower in the liver of undernourished chickens ( $285 \pm 186$ pmole ${ }^{3} \mathrm{H}-\mathrm{UTP} / \mathrm{g}$ tissue), but these differences were not statistically significant.

Feeding the chicken with low protein diet followed by realimentation with high protein diet did not evoke significant changes in the activity of the polymerase I and II in the liver.

\section{Activity of RNA polymerases in the breast muscle}

\section{Activity of polymerase I}

Activity of polymerase I in breast muscle of control and realimented chickens of approximately $450 \mathrm{~g}$ body weight did not differ significantly and amounted respectively $197 \pm 34$ and $260 \pm 74$ pmole ${ }^{3} \mathrm{H}-\mathrm{UTP} / \mathrm{g}$ tissue. On the other hand in the breast muscle of low-protein fed birds this activity was significantly $(\mathrm{P}<0.05)$ lower $\left(136 \pm 52\right.$ pmole ${ }^{3} \mathrm{H}-\mathrm{UTP} / \mathrm{g}$ tissue $)$ in comparison with the activity determined in breast muscle of realimented chickens (Table 2). There was also significant $(\mathrm{P}<0.01)$ increase of the activity of polymerase $\mathrm{I}$ in breast muscle of realimented chickens from the level of activity of this enzyme prior to realimentation in comparison with the activity during low-protein feeding period. At the same period no similar changes in the activity of polymerase $I$ in breast muscle of the control and undernourished chickens were found.

\section{Activity of polymerase II}

No significant differences in polymerase II activity in breast muscle of all groups of chickens weighing approximately $450 \mathrm{~g}$ (Table 3 ) were found. It should be pointed out, however, that this activity was higher in the breast muscle of the realimented chickens and amounted to $109 \pm 51$ pmole ${ }^{3} \mathrm{H}-\mathrm{UTP} / \mathrm{g}$ tissue/against $65 \pm 31 \mathrm{pmole}{ }^{3} \mathrm{H}-\mathrm{UTP} / \mathrm{g}$ tissue in the breast muscle of the control and low-protein fed chickens. During realimentation period polymerase II activity in the breast muscle significantly increased $(\mathrm{P}<0.05)$ so that at the end of realimentation this activity was considerably higher than prior to it.

Significant increase of the activty of polymerase I and II in the breast muscle of realimented chickens suggests a possibility of regulation the protein biosynthesis in the muscles on the level of transcription by the changes of either content or activity of RNA polymerases.

\section{DISCUSSION}

The effect of RNA polymerases activity, dependent on DNA, on rate of protein synthesis in the liver and breast muscle of chickens is very poorly 
understood. The aim of the present study was to elucidate whether or not activity of these enzymes in the liver and breast muscle of the chickens fed on low protein diet and then realimented was higher than in control birds. Von der Decken and Omstedt (1972) and Andersson and von der Decken (1975) pointed out that activity of RNA polymerases in liver of the rat depends on protein content in the diet. These authors also found that in animals fed the diet with low protein level the weight of the liver decreases.

Andersson and von der Decken (1975) obtained different results when expressed RNA polymerases activity per $\mathrm{mg}$ of protein and per gram of the tissue, the last method provided most reliable information. Therefore we used this method of presentation of our results.

In our studies on compensatory growth in chickens we found distinct differences among groups in RNA polymerases activity in breast muscle and lack of such differences in liver. The differences in I and II polymerases activity in liver, although visible, were statistically insignificant. As a result of individual variability in activity of these enzymes statistical significance was not reached. More clearly differentiated results on RNA polymerases activity were found in studies on breast muscles of chickens. Increased level of protein in the diet evoked an increase of the activity of polymerase II synthetizing mRNA, so that in all experiments this activity was higher in realimented chickens than in control and undernourished. The rise of polymerase II activity in breast muscle of the realimented chickens suggests that a change of RNA polymerases activity may be involved in regulation of transcription. It would be useful to check validity of this suggestion by studying the changes in RNA polymerases activity during the whole period of realimentation in order to help clarify the nature of this mechanism.

\section{AKNOWLEDGEMENTS}

We are highly indebted to Professor Piotr Chomczyński for considerable help in the RNA polymerases assays.

The help of Professor Grażyna Znaniecka in the design of nutritional experiments is aknowledged. We also greatly appreciate the valuable discussion and critical remarks on this manuscript from Professor Piotr Poczopko.

Supported by the Committee of Scientific Research Grant No. 500569101.

\section{REFERENCES}

Andersson G. M., von der Decken A., 1975. Deoxyribonucleic acid-dependent ribonucleic acid polymerase activity in rat liver after protein restriction. Biochem. J. 148, 49-56

Burton K. 1956. A study of the conditions and mechanism of the diphenylamine reaction for the colorimetric estimation of deoxyribonucleic acid. Biochem. J. 62, 315-323 
Chesterson C. J., 1971. Butterworth P. H. W. -- A new form of mammalian DNA-dependent RNA polymerase and its relationship to the know forms of the enzyme. FEBS Lett. 12, 301-308

Chomczyński P., Topper Y. J., 1974. A direct effect of prolactin and placental lactogen on mammary epithelial nuclei. Biochem. Biophys. Res. Commun. 60, 56-63

Chomczyński P., Sokól Misiak W., Kleczkowska D., 1977. Activity of DNA-dependent RNA polymerases in rabbit mammary gland during lactogenesis. FEBS Lett. 76, 191-194

Kedinger C., Gniazdowski M., Mandel Jr. J. L., Gissinger F., Chambon P., 1970, $\alpha$-amanitin: a specific inhibitor of one of two DNA-dependent RNA polymerase activities from calf thymus. Biochem. Biophys. Res. Commun. 38, 165-171

Kielanowski J., Keller J., 1962. Eine Methode quantitativer Einzelfutterung von Kuken. Arch. Tierernähr. 12, 261-267

Kleczkowska D., Chomczyński P., 1976. Cyclic purine nucleotides as modulators of RNA systhesis in rabbit mammary gland nuclei. Bull. Acad. Pol. Sci. Ser. Biol. 24, 189-193

Latchman D. S., 1990. Eukaryotic transcription factors. Biochem. J. 270, 281 289

Lindell T. J., Weinberg F., Morris P. W., Roeder R. G., Rutter W. J., 1970. Specific inhibition of nuclear RNA polymerase II by $\alpha$-amanitin. Science $170,447-448$

Lowry O. H., Rosebrough N. J., Farr A. L., Randall R. J., 1951. Protein measurement with the Folin phenol reagent. J. Biol. Chem. 193, 265-275

Reeder R. H., Roeder R. G., 1972. Ribosomal RNA synthesis in isolated nuclei. J. Mol. Biol. 67, 433-441

Roeder R. G., Rutter W. J., 1969. Multiple forms of DNA-dependent RNA polymerase in eukaryotic organisms. Nature, London 224, 234.237

Roeder R. G., Rutter W. J., 1970. Specific nucleolar and nucleoplasmic RNA polymerases. Proc. Nat. Acad. Sci. USA 65, 675682

Roeder R. G., 1974. Multiple forms of deoxyribonucleic acid-dependent ribonucleic acid polymerase in Xenopus laevis. J. Biol. Chem. 249, 241248

Shaw C., Fillios L. C., 1968. RNA polymerase activities and other aspects of hepatic protein synthesis during early protein depletion in the rat. J. Nutr. 96, 327-336

Von der Decken A., Andersson G. M., 1972. Effect of protein intake on DNA dependent RNA-polymerase activity and protein synthesis in vitro in rat liver and brain. Nutr. Rep. Int. 5,413419

Von der Decken A., Omstedt P. T., 1972. Dietary protein quality measured by in vitro protein synthesis in rat skeletal muscie ribosomes. J. Nutr. 102, 1555-1562

Weinmann R., Roeder R. G., 1974. Role of DNA-dependent RNA polymerase 111 in the transcription of the RNA and 5sRNA genes. Proc. Nat. Acad. Sci. USA 71, 1790-1794

Widnell C. C., Tata J. R., 1964. Evidence for two DNA-dependent RNA polymerase activities in isolated rat liver nuclei. Biochim. Biophys. Acta 87, 531-543

Widnell C. C., Tata J. R., 1966. Studies on the stimulation by ammonium sulphate of the DNA-dependent RNA polymerase of isolated rat liver nuclei. Biochim. Biophys. Acta 123, 478-492

Zylber E. A., Penman S., 1971. Products of RNA polymerases in HeLa cell nuclei. Proc. Nat. Acad. Sci. USA $68,2861-2865$

\section{STRESZCZENIE}

Aktywność polimeraz RNA w wątrobie i mięśniu piersiowym kurcząt po ograniczeniu podawania bialka

Doświadczenie przeprowadzono na 36 jednodniowych kurczętach, które karmiono mieszanką Starter dla brojlerów do wieku 11 dni. Następnie 6 kurcząt (grupa zero) zabito. Pozostałe ptaki podzielono na 3 grupy: kontrola $(\mathrm{C})$, niedożywione (U) i realimentowane $(\mathrm{R})$. Dwic izokaloryczne diety zawierające różny procent białka $(12,9 \%$ - LP i $22,6 \%$ - HP) skarmiano przymusowo. 
Doświadczenie podzielono na dwa okresy: w pierwszym średnia masa ciała zwiększyła się z 134 do 250 gramów, w drugim z 250 do 450 gramów. Przez całe doświadczenie kurczęta grupy C żywiono dietą HP, kurczęta z grupy U dietą LP. Grupa R otrzymywała dietę LP, a następnie w drugim okresie dietę HP. Na końcu pierwszego okresu 6 kurcząt $\mathrm{z}$ grupy $\mathrm{C}$ i $6 \mathrm{z}$ grupy $\mathrm{U}$, na końcu drugiego okresu po 6 kurcząt z grup C, U i R ubito dla oznaczenia aktywności polimeraz RNA w wątrobie i mięśniu piersiowym.

Zastosowany układ żywienia nie miał istotnego wpływu na aktywność polimeraz I i II wątroby, natomiast wpłynął istotnie na wzrost aktywności tych enzymów w mięśniu piersiowym kurcząt z grupy R. Sugeruje to możliwość regulacji biosyntezy białka na poziomie transkrypcji przez zmianę zawartości polimeraz RNA. 